Copyright (C) 2021 The Author/s

This work is licensed under a CC-BY 3.0 License

Peer review method: Double-Blind

Accepted: August 08, 2021

Published: September 21, 2021

Review article

DOI: https://doi.org/10.47305/JLIA2137267|

\title{
ANONYMITY AND OPENNESS IN GAMETE DONATION: THE RUSSIAN POLICY ON THE THIRD-PARTY REPRODUCTION
}

\author{
Rafał Łukasiewicz* \\ University of Rzeszów, Poland \\ ORCID iD: https://orcid.org/0000-0003-4054-7492 \\ rlukasiewicz@ur.edu.pl \\ Angelo Viglianisi Ferraro \\ University "Meditarranea" of Reggio Calabria, Italy \\ ORCID iD: https://orcid.org/0000-0002-6480-3684 \\ avf@unirc.it
}

\begin{abstract}
The Russian Federation is one of the few jurisdictions where recipients and gamete donors have a wide scope of choice between anonymous, identifiable, and known donations. This paper examines how the Russian law regulates this sphere and how it is applied in practice basing on data collected in the largest reproductive cells bank in Russia. It demonstrates that the Russian Federation should be regarded as a country in which there is no single dominant approach to the matter of donor anonymity. The assessment of this 'freedom of choice' is not unambiguous. It gives recipients and donors the right to decide which option is the most suitable for their needs and motivations, simultaneously not resolving which values take precedence over others. The donor-conceived persons' right to disclose donor's identifying data sometimes may conflict with the donor's right to protect their privacy and usually, jurisdictions decide which one has the priority.
\end{abstract}

Keywords: Anonymous; Non-Anonymous; Donor; Gamete Donation; Russia

\section{INTRODUCTION}

Legal regulations concerning third-party reproduction vary significantly all over the world. In some jurisdictions, donor's anonymity is unflinching and supported by law. Others amend their laws towards the removal of anonymity. Both of those different systems are sometimes supplemented by permission to use known donors, such as family members. In the majority of jurisdictions, the law explicitly indicates if gamete donation is anonymous or identifiable. A decision on the choice between those two types of donation is rarely passed on to involved parties - recipients, donors, and donor- 
conceived offspring. The Russian law combines two approaches to release donor's identity giving donors and recipients a choice between anonymous donation and identifiable donation. The main difference between anonymous and identifiable donations concerns a child's right to find out the identity of a donor. In anonymous and in identifiable donation a donor's identity is unknown for recipients and vice versa. However, in identifiable donation, a child who reaches the specified age has access to identifying information about the donor. The third option accessible for donors and recipients is known donation (e.g. donor is a family member of recipients) which is also possible in the Russian Federation. The following analysis examines how original the Russian law is in comparison to other European jurisdictions, how the provisions on donor's anonymity and identification are designed, and how the law is applied in practice, including some statistical data from the largest reproductive cells bank in Russia.

In some countries, only one type of gamete donation is permitted, but in others, the choice is between anonymous and known donation or between identifiable and known donation. "The triple-track system" (Pennings 2016, 116) gives a chance to choose between all three types of gamete donation (anonymous, identifiable, and known) and the Russian Federation is one of the few countries that use this model. This system is not well-researched, in particular taking statistical data and practical issues into account. The focus of this paper is to present which type of donors (anonymous or identifiable) are more popular if recipients have the right to decide. As such the Russian case is unique, as the comparison of the number of recipients who choose anonymous donors and identifiable donors is difficult to conduct in most countries because laws usually permit only one of them.

\section{THE RUSSIAN 'TRIPLE-TRACK SYSTEM’ ON THE BACKGROUND OF THE EUROPEAN LAWS}

Medically assisted reproduction (MAR) using a third party is strictly connected with the problem of disclosure of information about donors. A consideration of legal regulations concerning donor-conceived child's right to identify their donor leads to a conclusion that ethical and legal approaches towards this matter are different all over the world (Allan 2017, Blyth and Frith 2009, 175-191; Pennings et al. 2014, 1076-1098, Calhaz-Jorge et al. 2020, 9). As mentioned above, three types of gamete donation can be distinguished - anonymous donation, identifiable donation, and known donation. This wide range of choices is called a 'triple-track system', but it is not commonly practiced in a large number of jurisdictions. In some laws donors and recipients do not have a choice at all (e.g. in Poland - only anonymous donation or in Portugal - only identifiable donation). In others, they can choose between only two options (e.g. in Belgium - between anonymous and known donation or in the United Kingdom - 
between identifiable and known donation). Nevertheless, the 'triple-track system' is accessible for donors and recipients in some jurisdictions, for instance in Iceland and as the further analysis demonstrates - in the Russian Federation. The trend towards the disclosure of a donor's identity has been noticeable in Western European legislation (Sweden, Austria, Switzerland, the Netherlands, Norway, the United Kingdom, Finland, and Portugal). The abolishment of anonymous donation is supported by Recommendation 2156 (2019) 'Anonymous donation of sperm and oocytes: balancing the rights of parents, donors and children' (the Parliamentary Assembly of Council of Europe), which recommends identifiable and in exceptional circumstances known donation. According to section 7.1. of the Recommendation 2156 (2019):

Anonymity should be waived for all future gamete donations in Council of Europe member States, and the use of anonymously donated sperm and oocytes should be prohibited. This would mean that (except in exceptional cases, when the donation is from a close relative or friend) the donor's identity would not be revealed to the family at the time of the donation, but to the donor-conceived child upon their 16th or 18th birthday. The donor-conceived child would be informed at that time (ideally by the State) of the existence of supplementary information on the circumstances of their birth. The donor-conceived person could then decide whether and when to access this information containing the identity of the donor, and whether to initiate contact (ideally after having had access to appropriate guidance, counselling, and support services before making a decision.

This tendency does not occur in Central and Eastern Europe. Most of these countries permit only anonymous donations (e.g. Poland, the Czech Republic) but some of them accept known donations too (e.g. Ukraine, Bulgaria). The most important legal acts regulating infertility treatment in the Russian Federation are:

- Federal Law No. 323-FZ of 21 November 2011 on the Fundamentals of Protection of the Public health (hereinafter 'the Federal Law'),

- Order No. 107n of 30 August 2012 on the use of Assisted reproductive technologies, Contradictions, and restrictions on their use (hereinafter 'the Order').

- Clinical recommendations No. 15-4/И/2-1908 of 5 March 2019 on Assisted Reproductive Technologies Treatment (hereinafter 'the Recommendations').

The basic legal framework on medically assisted reproduction is established in article 55 of the Federal Law. It does not regulate which types of donation (anonymous, identifiable, or known) are permitted or prohibited in the Russian Federation (Svitnev 2012, 2; Maleshina 2020, 36-43; Savvina 2019, 19-26). However, article 55.8 of the Federal Law regulates the right to receive information about the results of the medical 
and genetic examination of the donor, their race and nationality, and their appearance. Legal regulations about the content of this right are different across the world, in particular concerning the donor-conceived person's right to disclose information about their donor. In some jurisdictions, this access is limited only to non-identifying information e.g. in Poland and Greece. In others, a donor-conceived child has an access to identifying information about their donor, e.g. in the United Kingdom and Sweden. However, it is important to note, that the scope of information (non-identifying and/or identifying) differs among jurisdictions.

Medically assisted reproduction is regulated in a more detailed way in the Order. Regarding the considered matter, the most important problem is the distinction between types of gamete donation that are accessible for donors and recipients. According to articles 54 and 62 of the Order, sperm donors and oocyte donors could be anonymous or non-anonymous. As mentioned above, there is no exact definition of those two types of donations. In particular, non-anonymous donations could be understood as identifiable donations or as known donations, but also as both of them.

According to articles 56 and 65 of the Order, individual cards are prepared for sperm and oocyte donors (Appendix No. 4 and 5). Regarding a sperm donor, Appendix No. 4 includes the following information: full name, date of birth, nationality, race, place of permanent registration, contact number, education, profession, harmful and/or hazardous production factors, marital status, presence of children, inherited diseases in the family, bad habits (smoking, alcohol, drugs and/or psychotropic substances without a doctor's prescription). There is also information concerning some diseases, such as syphilis, gonorrhea, hepatitis, HIV, and information about being under skin-venereologic or neuropsychiatric medical observation.

Moreover, phenotypic features are noted (height, weight, hair type and hair color, eye shape and eye color, nose shape, face shape, presence of stigma, shape of forehead), and additional information about a donor (optional). Furthermore, Appendix No. 4 contains a sperm donor's medical examination card, sperm donor medical examination calendar, and sperm donor survey sheet which is filled in before each delivery of sperm. Regarding oocyte donors, Appendix No. 5 contains a similar scope of data. There are some additional data such as the build of body and bra size, but there is no information about the medical examination calendar and survey sheet which is filled before each delivery of oocyte. There is also information about examinations, but the types of them are not the same in comparison to a sperm donor.

With regards to sperm donation, article 66 of the Order regulates that to facilitate the selection of a donor, a list of sperm donors is formed with information about the appearance of the donor such as height, weight, eye color, hair color, the shape of the nose, ears, and others, as well as the results of a medical and genetic examination of the donor, his race and nationality. At the same time, it is worth emphasizing that the Order does not establish a similar regulation regarding oocyte donation. 
The Recommendation distinguishes anonymous (in which the donor's data are unknown to the recipient) and non-anonymous gamete donation. There is no additional description of requirements and details concerning these two types of gamete donation, such as a scope of information accessible to a donor-conceived child.

\section{THE 'TRIPLE-TRACK SYSTEM' IN THE RUSSIAN PRACTICE}

In the light of the above considerations, the Russian legal system regulates anonymous and non-anonymous donation only in general terms. This legal framework is complemented by standards that are commonly used in Russian practice. In this part of the paper, such practices are analyzed taking into account the activity of the Russian largest reproductive cell bank and IVF clinics.

According to the figures provided by Reprobank $\AA$ (Personal communication with Avtandil Chogovadze, M.D., CEO at Reprobank ${ }^{\circledR}$, March 2020), various types of donations are used in practice. Among the current 63 active egg donors, there are 23 $(\approx 36.5 \%)$ donors who are anonymous, $38(\approx 60.3 \%)$ donors who are identifiable, and 2 $(\approx 3.2 \%)$ donors who want to be known also for recipients. However, Reprobank $₫$ does not act as an intermediary in this kind of contact (Personal communication with Avtandil Chogovadze, M.D., CEO at Reprobank ${ }^{\circledR}$, March 2020). Among the current 56 active sperm donors, there are $17(\approx 30.4 \%)$ donors who are anonymous and 39 ( $\approx 69.6 \%)$ donors who are identifiable.

As for anonymous donations, a donor-conceived child who reaches the age of 18 can request information about their donor. Reprobank ${ }^{\circledR}$ supplies this information from their records or by attempting to ask a donor. A donor-conceived child can also request to initiate an anonymous contact with a donor. If there is mutual consent on both sides, it is possible to establish contact through e-mails, written letters, or a voice conversation. Nevertheless, even in cases of an anonymous donation, it is possible to moderate a direct contact between the donor and donor conceived-child if they mutually agree on it. Regarding identifiable donors, a donor agrees to at least one contact with a child who reaches the age of 18. It could take the form of in-person meetings if there is mutual consent. Further contacts are not obligatory for the donor. The Russian law does not protect the donor-conceived child's right to contact with the donor. Even if a donor has decided to be identifiable, their consent to communication is not binding at all.

Notwithstanding article 55.8 of the Federal Law, in practice, a donor conceivedchild has access to a large amount of information about their donor. However, the level of anonymity (openness) depends on the donor's decision. Regarding sperm donors, the Reprobank ${ }^{\circledR}$ website contains a list of donors with detailed information about them. The data is open for every visitor of this website (Reprobank $®$ website, April 2020). In practice, donors provide more information in comparison to the content of article 55 of 
the Federal Law. The description of their appearance is more detailed (e.g. drawings of facial parts to choose the most similar to the donor's face). There is also information about the type of donation (anonymous or non-anonymous), their faith, or zodiac sign. Additionally, there are separate pieces of paper with a story of the donor's family and a story of the donor about himself or herself. Every profile contains a photo of a donor as a baby. However, 11 of the current active donors in Reprobank ${ }^{\circledR}$ (also anonymous) agreed to present recipients with their adult photos (Personal communication with Avtandil Chogovadze, M.D., CEO at Reprobank ${ }^{\circledR}$, March 2020). There is also information about additional data about donors which could be presented during a consultation, such as an extended profile, photos of children, creative tasks, facial features, recording of their voice, Keirsey Temperament Sorter, and question test.

The term 'known donation' means that the recipients and the donor know each other from the beginning. This term is used about gamete donation between family members, friends, or another known person. In some jurisdictions, there are specific requirements regarding known donations, which limit it only to family members and/or egg donors (e.g. in Ukraine). However, much more often legal systems do not regulate known donations in a detailed way (e.g. in Belgium, Iceland). In many IVF clinics in the Russian Federation recipients can find a donor on their own. Known donation is commonly offered by IVF clinics in the Russian Federation (e.g. information on O.L.G.A. Fertility Clinic's website, LifeLine Center of Reproduction's website, April 2020). The law does not regulate those cases in a specific way, but in practice, it is often limited only to relatives or acquaintances.

\section{CONCLUSION}

Nowadays, a trend towards the openness of a donor's identity can be observed all over the world. Nevertheless, the anonymity of donation is accepted by societies and laws in the majority of countries. The Russian law distinguishes two types of gamete donation - anonymous donation and non-anonymous donation. However, the content of those two terms is not precisely defined by the law. The above research about gamete donation in the Russian Federation was not limited to legal acts and it showed that in fact, three types of donation occur in the Russian practice (anonymous, identifiable, and known). Furthermore, even if the donation is anonymous, the donorconceived offspring have the right to receive a wide scope of non-identifying information about the donor. The identification of a donor may be the result of their consent given in the past, but it may be also based on subsequent mutual consent, which allows even in-person meetings between a donor and a donor-conceived person.

The anonymity of donation is still an important value of gamete donation in Russia (Khayat, Kurilo, Chernykh 2017, 59; Sukhareva 2014, 22-28), but according to present statistical data of current active donors in Reprobank ${ }^{\circledR}$, an identifiable donation 
is also a popular option for donors and recipients (Personal communication with Avtandil Chogovadze, M.D., CEO at Reprobank $\AA$, March 2020). In practice, the donor's and the donor-conceived child's mutual consent is a basic requirement of contacts between them in the Russian Federation. However, only a donor-conceived child has a right to initiate those contacts. Moreover, known donations are also practiced by IVF clinics.

This analysis does not attempt to answer the question of which type of gamete donation (anonymous or identifiable) is more appropriate. In the last few decades the problem of donor's anonymity has been lively debated (Allan 2017; Cahn 2012, 367-430 Cohen 2012, 431-447; Daniels and Taylor 1993, 155-170; Ravelingien et al. 2015, 503509; Frith 2001, 473-484; Frith 2015, 29-44; Frith et al. 2018, 188-203).

This paper rather pays attention to the possibility of simultaneous existence of both of them in the framework of one jurisdiction. The legal and ethical assessment of the Russian model of gamete donation should consider two aspects. The first one is the examination of possible benefits and risks of access to both anonymous and identifiable donations in one legal system. The second is whether the admissibility of known donations, especially between family members, could be accepted from the child's welfare point of view.

The first issue was analyzed by Guido Pennings, who proposed the so-called 'double-track' policy. According to this policy 'a donor has a choice to enter the program as an anonymous or as an identifiable donor and recipients can choose between an identifiable or an anonymous donor'. Pennings defined also the term 'tripletrack system' a as "variety of options, including known, anonymous, and identifiable donors" (Pennings 2016, 116). What is most important, however, is the fact that the possibility of choice between anonymous and identifiable donations is not commonly regulated all over the world. In the majority of jurisdictions, the choice is rather between anonymous and known or between identifiable and known donations. Pennings concluded that:

The 'double track' policy for anonymity represents the best attempt to balance the rights of donors, recipients, and donor offspring. It offers the social parents the freedom to choose the degree to which they want the donor involved in their new family. It also enables donors to define their commitment. Moreover, it also expresses the idea that there is no unique and universal optimal solution (Pennings 1997, 2839-2843).

The Russian Federation is a country in which donors and recipients decide which type of gamete donation meets their expectations. In comparison with other European countries, this approach is rather uncommon. Although the 'triple-track system' may seem like a solution that takes all involved parties' interests into account the position between donor-conceived offspring differs in one legal system which makes the legal 
accessibility of both, anonymous and identifiable donations debatable. Donors and recipients can choose a certain level of anonymity of donation and donor-conceived persons have the right to obtain a wide scope of non-identifying information about their donor. Nevertheless, it still does not give all donor-conceived persons the right to receive identifying information about their donors. Some donors remain anonymous for donor-conceived persons, whereas some other donors can be identified by them. Consequently, important questions arise: why the legal position of donor-conceived persons is not the same and which type of donation (anonymous or identifiable) is consistent with the principle of the best interest of a child?

On the other hand, the legal regulations concerning secrecy or disclosure of donors' identity are not unified even in the European jurisdictions. Notwithstanding the increasing criticism of the anonymity of donation and the amendment of laws towards openness, in many countries, donors are still anonymous. Giving the fact that crossborder MAR is available for recipients and donors without any limitations, the variety of choice is even wider than in the 'triple-track system'.

The choice is not only between an anonymous, identifiable, and known donation but also between different models of those types of gamete donation. For example, the anonymous donation does not mean the same in all jurisdictions, but it varies in some countries concerning the scope of donor's non-identifying data that is accessible for donor-conceived persons. Looking at the problem of donors' anonymity from the international perspective, it is worth pointing out that nowadays 'the world has become a global village' and the 'triple-track system', though on a bigger scale, is the real choice that recipients and donors have. Remembering that donor-matching in Russia is based on the consumer-direct model giving recipients a great impact on donor selection, the Russian Federation might be a very popular direction for people searching a donor with specific features, including searching a donor with the desired level of disclosure of their data. Indeed, it is worth noting that the development of cross-border reproductive MAR influences also Russia regarding surrogate motherhood (Nygren et al. 2010, 4; Salama et al. 2018, 1279-84; Svitnev 2012, 2-3; Borisova 2021; Novikov 2019, 301-325). The consumer-direct model and the 'triple-track system' might also lead to the rise of crossborder MAR to the Russian Federation.

Regarding known donors, it is worth emphasizing that most of them are family members of recipients (intra-family gamete donation). The studies concerning this issue have been focused on risks associated with an extraordinary situation in which a donor and recipients are members of the same family. In particular, a problem of different social roles and genetic truth has to be considered, for instance, when a genetic mother is the social aunt of a donor-conceived child (Vayena and Golombok 2012, 174-175; Yee et al. 2007, 2047; Marshall 1998, 1172-1173; de Wert et al. 2011, 506). The results of the above-mentioned studies reveal that intra-family gamete donation does not harm a child's welfare (Lessor 1993, 409-410; Winter and Daniluk 2004, 486-490). 
However, it must be stressed that the Russian Law does not limit known donations only to a donation between family members. Russian IVF clinics do not have sufficient instruments to verify if a person called by recipients as an 'acquaintance' is actually a close person to them or maybe he or she may have received informal payment for donating their gametes. The 'freedom of choice' approach may be viewed as based on 'free-market principles' because it gives recipients full flexibility in choosing between an anonymous donation, identifiable donation, and known donation. However, it does not answer the question of whether the donor-conceived persons' right to know their genetic origins and identification of donors is more important than the rule of donors' anonymity and protection of their privacy. It is therefore difficult to comprehend what is the rational justification for unequal donor-conceived persons' rights regarding the right to find out donors' identity. Donor-conceived offspring are not involved in the decision-making process and they do not influence the choice of an anonymous donor and their subsequent refusal to contact them. 


\section{ACKNOWLEDGEMENTS}

The presented paper is based on research conducted by Rafał Łukasiewicz which was done within his participation in Erasmus+ Program Staff Mobility for Training: Job Shadowing at the Russian State Social University in Moscow. The statistical data was collected thanks to the Reprobank ${ }^{\circledR}$ Reproductive cell bank in Moscow. The author would like to thank Avtandil Chogovadze, M.D., CEO at Reprobank ${ }^{\circledR}$ for his assistance with collecting data about current active donors in their database. The above work has been developed by research conducted by Angelo Viglianisi Ferraro. 


\section{REFERENCES}

1. Allan, Sonia. 2017. Donor Conception and the Search for Information: From Secrecy and Anonymity to Openness. London, New York, Routledge Taylor \& Francis Group.

2. Blyth, Eric, and Frith, Lucy. 2009. "Donor-conceived People's Access to Genetic and Biographical History: an Analysis of Provisions in Different Jurisdiction Permitting Disclosure of Donor Identity.", International Journal of Law, Policy and the Family 23:174-91. doi:10.1093/lawfam/ebp002.

3. Borisova Tatiana E. 2012. Surrogacy in the Russian Federation: Theoretical and Practical Issues: Monograph, Moscow, Prospect [Борисова T.E. 2012. Суррогатное. материнство в Российской Федерации: проблемы теории и практики: монография, Москва Проспект].

4. Cahn, Naomi. 2012. "The New Kinship." Georgetown Law Journa/ 100(2): 367-429. https://papers.ssrn.com/sol3/papers.cfm?abstract_id=2018969.

5. Calhaz-Jorge, Carlos, De Geyter, Christian, and Kupka. Marcus S., et al. 2020. "Survey on ART and IUI: Legislation, Regulation, Dunding, and Registries in European Countries. The European IVF-monitoring Consortium (EIM) for the European Society of Human Reproduction and Embryology (ESHRE)." Human Reproduction Open. doi:10.1093/hropen/hoz044.

6. Cohen Glenn. 1993. "Response: Rethinking Sperm-Donor Anonymity: Of Changed Selves, Non-identity, and One-Night Stands." Georgetown Law Journal 100(2):431-33.

https://papers.ssrn.com/sol3/papers.cfm?abstract_id =1961605

7. Daniels, Ken R. and Taylor, Karyn 1993. "Secrecy and Openness in Donor Insemination.", Politics and the Life Sciences 12(2):155-170. doi:10.1017/S0730938400023984.

8. de Wert, Guido, Dondorp, Wybo and Pennings. Guido et al. (2011). "Intrafamilial Medically Assisted Reproduction." Human Reproduction 26(3):504-9. doi:10.1093/humrep/deq383.

9. Frith, Lucy. 2001. "Beneath the Rhetoric: The Role of Rights in the Practice of NonAnonymous Gamete Donation.", Bioethics 15(5/6):473-84. doi:10.1111/14678519.00255

10. Frith, Lucy, Blyth, Eric and Crawshaw Marilyn, and van den Akker Olga. 2018. "Secrets and Disclosure of Gamete Donation." Sociology of Health \& IIIness 40(1):188-203. doi:10.1111/1467-9566.12633

11. Frith, Lucy. 2015. "The Limits of Evidence: Evidence-Based Policy and the Removal of Gamete Donor Anonymity in the UK.", Monash Bioethics Review 33(1):29-44. doi:10.1007/s40592-015-0017-z. 
12. Khayat, Sabina Sh., Kurilo, Lyubov F. and Chernykh, Vyacheslav B. 2017. "Ethical and Legal Issues of Anonymous Sperm Donation" Andrology and Genital Surgery 18(4):57-60 [Хаят С. Ш., Курило Л. Ф., Черных В. Б., Этико-правовые проблемы анонимности доноров эякулята, Андрология и Генитальная Хирургия 18(4):57-60] doi:10.17650/2070-9781-2017-18-4-57-60

13. Lessor, Roberta. 1993. "All in the Family. Social Processes in Ovarian Egg Donation Between Sisters." Sociology of Health and Illness 15(3):394-413. doi:10.1111/1467-9566.ep10490713.

14. Maleshina, Anastasia. 2020. "Taking Human Reproductive Rights Seriously: The Russian Perspective." Russian Law Journa/ 8(1)25-59. doi:10.17589/2309-86782020-8-1-25-59.

15. Marshall, Lorna A. 1998. "Intergenerational Gamete Donation. Ethical and Societal Implications." American Journal of Obstetrics and Gynecology 178(6):1171-6. doi:10.1016/S0002-9378(98)70319-9.

16. Novikov, Andrei A. 2019. "Surrogate Motherhood in Russia and the Commonwealth of Independent States: Legislation, Jurisprudence, and Political Discussion." In Fundamental Legal Problems of Surrogate

Motherhood. Global Perspective edited by Mostowik, Piotr 301-365 Warsaw, Wydawnictwo Instytutu Wymiaru Sprawiedliwości.

17. Nygren, Karl, Adamson, David, Zegers-Hochschild, Fernando and de Mouzon Jacques. 2010. "Cross-Border Fertility Care — International Committee Monitoring Assisted Reproductive Technologies Global Survey: 2006 Data and Estimates." Fertility and Sterility 94(1):e4-e10. doi: 10.1016/j.fertnstert.2009.12.049.

18. Pennings, Guido, de Mouzon, Jacques, Shenfield, Francoise, Ferraretti, Anna Pia et al. 2014. "Socio-Demographic and Fertility-Related Characteristics and Motivations of Oocyte Donors in Eleven European Countries." Human Reproduction 29(5):1076-89. doi:10.1093/humrep/deu048.

19. Pennings, Guido. 1997. "The 'Double Track' Policy for Donor Anonymity." Human Reproduction 12(12):2839-2844. doi:10.1093/humrep/12.12.2839.

20. Pennings, Guido. 2016. "The Non-Anonymous Sperm Donor: What do we Know and Where do we go?" Médecine de la Reproduction, Gynécologie Endocrinologie 18(2):116-122. doi:10.1684/mte.2016.0603.

21. Ravelingien, An, Provoost, Veerle and Pennings, Guido. 2015. "Open-Identity Sperm Donation: How Does Offering Donor-Identifying Information Relate to Donor-Conceived Offspring's Wishes and Needs?" Journal of Bioethical Inquiry 12(3):503-9. doi:10.1080/13691058.2014.979883.

22. Salama, Mahmoud, Isachenko, Vladimir, Isachenko Evgenia, Rahimi, Gohar et al. 2018. "Cross Border Reproductive Care (CBRC): a Growing Global Phenomenon with Multidimensional Implications (a Systematic and Critical Review)." Journal of 
Assisted Reproduction and Genetics 35(7):1277-88. doi:10.1007/s10815-0181181-x.

23. Savvina Olga V. 2019. "Ethical foundations for the regulation of gamet donation and co-parenting practices" Actual Problems of Russian law 4(101):19-26. [Саввина Ольга В. 2019. "Этические основания регулирования донации гамет и практики co-parenting", Актуальные проблемы российского права 4(101):19-26]. doi:10.17803/1994-1471.2019.101.4.019-026.

24. Sukhareva, Elena R. 2014, "Judicial Problems of Modern Reproductive Technologies: Genetic Material and Anonymity of Donors", Vestnik of the Voronezh Institute of MIA of the Russian Federation, 2:22-28. [Сухарева E.P. 2014 Правовые проблемы современных репродуктивных технологий: генный материал и анонимность доноров, Вестник Воронежского института МВД России, 2:22-28.

25. Svitnev, Konstantin. 2012. "New Russian Legislation on Assisted Reproduction." Journal of Clinical Research \& Bioethics 1(3):1-3. doi:10.4172/scientificreports.207.

26. Vayena, Effy, Golombok, Susan. 2012. "Challenges in Intra-Family Donation" In Reproductive Donation. Practice, Policy, and Bioethics edited by Richards, Martin, Pennings Guido, Appleby John B. 168-188, Cambridge, Cambridge University Press.

27. Winter, Alanna and Daniluk, Judith C. 2004. "A Gift from the Heart. The Experiences of Women Whose Egg Donation Helped Their Sisters Become Mothers" Journal of Counseling and Development 82(4):483-94. doi:10.1002/j.1556-6678.2004.tb00337.x.

28. Yee, Samantha, Hitkari, Jason A. and Greenblatt, Ellen M. 2007 "A Follow-Up Study of Women Who Donated Oocytes to Known Recipient Couples for Altruistic Reasons." Human Reproduction 22(7):2040-50.

doi:10.1093/humrep/dem103. 